\title{
DRINKING PERFORMANCE AND POLITICS IN PUEBLO BONITO, CHACO CANYON
}

\author{
Patricia L. Crown
}

\begin{abstract}
Drinking vessels provide information on changes in drinking practices, crafting, exchange patterns, rituals, and the creation of status differences in Chacoan society. They reveal a gradual sequence of change in vessel forms, followed by dramatic intensification of drinking activity in the $A D$ 1000s that provided opportunities for differentiation among Chaco residents, particularly at Pueblo Bonito. Termination of the most iconic drinking vessel form, the cylinder vessel, and the rituals surrounding it around $A D 1100$ was followed by the introduction of a northern drinking vessel form. Careful reconstruction of the production, consumption, and discard practices associated with drinking vessels provides the means for understanding broader processes in the Chaco world.
\end{abstract}

Los recipientes cerámicos para beber proporcionan información sobre cambios en las prácticas de producción y consumo, los patrones de intercambio, los rituales y la creación de diferencias de estatus en la sociedad Chaco. El análisis de estos objetos revela una secuencia gradual de cambios en las formas de los recipientes, seguida por una intensificación dramática en su uso alrededor del siglo once dC, misma que proporcionó oportunidades de diferenciación entre los residentes del Chaco, particularmente en Pueblo Bonito. Alrededor de 1100 dC se observa la cesación del uso de la forma más icónica de estos recipientes para beber, el recipiente cilíndrico, y de los rituales asociados, seguida por la introducción de una forma de recipiente procedente del norte. La reconstrucción cuidadosa de las prácticas de producción, consumo y descarte asociadas con los recipientes para beber nos ayuda a entender los procesos más amplios que ocurrieron en el mundo del Chaco.

$\mathrm{H}$

umans must consume liquids to survive, but as with many aspects of human existence, drinking also provides an opportunity for elaboration that can lead to social differentiation, discrimination, and hierarchy. When we think about drinking in the past, we must consider the ingredients, the associated paraphernalia, the practices coupled with drink consumption, and the impact those had on a society. Societies also varied in the behavior associated with drinking special beverages, the amount consumed on a single occasion, who could drink and how often, how widely drinking occurred, the context of drinking, and the social response to drinking (Child et al. 1965), but these are difficult to determine in archaeological cultures without written records or drinking imagery. People made drinks out of a variety of ingredients, creating recipes that varied in strength and flavor, and then constructed hierarchies of beverages, with alcoholic drinks usually having the highest prestige in groups that had them (Vencl 1994:312).

In this article, I review anthropological theory focused on drinking. I discuss cross-cultural patterns in drinking vessel forms and how southwestern Pueblos performed drinking rituals ethnographically. I then focus on the production, consumption, and discard of drinking vessels found in Chaco Canyon between about AD 500 and 1200. I conclude that drinking rituals in Chaco intensified in the AD 1000s, followed by upheaval with the termination and rejection of their most iconic vessel form around AD 1100. While archaeologists working in the US Southwest/Mexican northwest (Southwest/Northwest) have written extensively about feasts and feasting in this area (Plog and Watson 2012; Potter 2000;

Patricia L. Crown — Department of Anthropology, MSC01-1040, University of New Mexico, Albuquerque, NM 87131-1086, USA (pcrown@unm.edu)

American Antiquity 83(3), 2018, pp. 387-406

Copyright (C 2018 by the Society for American Archaeology doi:10.1017/aaq.2018.12 
Spielmann 2002, 2004; Van Keuren 2004; Wills and Crown 2004), they have paid less attention to the drinks and associated paraphernalia that were important components of commensal politics.

\section{Forms}

Here I focus on the vessels, rather than other objects used to prepare or consume drinks, and I focus particularly on form rather than design, because distinctive drinking vessel forms are more closely tied to defined communities than decoration (Dietler and Herbich 1989:157). Worldwide, the earliest drinking vessels tend to have been made using natural materials, including gourds, calabashes, eggs, coconuts, shells, horns, wood, bone, skins, or skulls (Tedlock 2002; Vencl 1994:316). Often, people replaced these with ceramics that mimicked these forms, called skeuomorphs (Blitz 2015; Holmes 1886:446; Houston 2014), and then ceramics that elaborated these basic natural forms with decoration. In areas with metallurgy, metal forms replaced ceramics, or there might be both metal elite and ceramic nonelite versions of specific vessel forms (Joffe 1998:307; Sherratt 1995:20).

Drinks could be served in containers large enough for group consumption, for instance, with straws (Joffe 1998), or in smaller individual serving vessels. Communal drinking from large vessels promotes solidarity and egalitarian sharing (Rabinowitz 2009:143) because shared vessels emphasize the equality of the drinkers. However, such equality may be an illusion, perhaps "to ward off challenges to the existing order" (Day and Wilson 2004:55). In contrast, the use of individual drinking containers is associated with hierarchy and greater overt tensions within a community. Individual drinking containers permit personal elaboration (Heath 2000:119), with the size of individual vessels often relating to age and status (for example, highest-status males drank from larger vessels, with increasingly smaller vessels associated with younger age and lower status [Heath 2000:81]). It may be difficult to determine the number of participants from communal vessels, but with individual drinking vessels, more vessels may indicate more participants (Webb and Frankel 2008:293). The shift to individual serving vessels was often accompanied by a shift in the physical practice of drinking; individual vessels can be held by one hand and set on a surface where they are visible to other participants and associated with the drinker. The act of pouring may have become a greater focus of drinking practice, so that serving became more central (Day and Wilson 2004:55).

Special drinks such as wine, beer, chocolate, coffee, and tea tend to have distinctive groupspecific vessel forms. As the number of distinct drinks increases, each may have associated vessel forms, paraphernalia, etiquette, and ritualized behavior (Smith et al. 2003:247). For instance, wealthy Victorian place settings included up to 10 different shapes of stemware, as well as distinctive cups for coffee and tea. So not only drink-specific vessel forms but also the variety of vessel forms and associated drinks became important means of differentiation and hierarchy in sedentary societies (Hayden 1995:261; Smith et al. 2003:247). The more elaborate the social hierarchy, the more elaborate the drinking vessel assemblage and the greater the use of decoration and precious materials to differentiate forms (Anderson 2009). For archaeologists, then, an increase in the number of distinct drinking vessel forms is an indication of intensified drinking activity, particularly drinking in groups, and likely indicates varied recipes or rituals as well (Anderson 2009; Joyce and Henderson 2010:158; Smith et al. 2003). In complex societies, the number of distinct drinking vessel forms may decrease when they are produced by specialists (Hamilakis 1999:48-49).

While variety in vessel forms may relate to different social classes and drinks, and while distinct vessel forms mirror social distinctions (Mullins 2011:140), change in vessel form may relate to changes in religious practices, trade contacts, beverages, etiquette, or elite status markers (Arnold 1999:73; Powis et al. 2002). Furthermore, "every period and culture displaying a rapid morphological development of drinking vessels also accentuates the social functions of drinking" (Vencl 1994:317). New vessel shapes often point to changes in drinking practices connected with the development of new sociopolitical institutions and ideologies (Anderson 2009; Joffe 1998:306; Joyce and Henderson 2010:160), 
emphasizing the connection among drinking practices, ideology, and craft production. In Bolivia, drinking vessels and the associated rituals helped promote rapid social transformation (Anderson 2009:192). Indeed, because drinks require paraphernalia, drinking practices always impacted crafting (Berg 2007) or exchange. Authentic or emulated exotic drinking vessels may differentiate elite drinking even when the exotic drink itself was scarce (Dietler 1990:386). Thus, the vessel might come to symbolize the drink, regardless of the presence of the concoction. Opaque drinking forms may mask the quantity of drink, so that viewers believe there is more than there actually is. Restricted drink supplies often lead men to limit women's consumption (Bacon 1973:190) and ultimately to enact sumptuary laws or taboos. When drink is scarce, control over drinking is high (Douglas 1987).

\section{Uses}

Cross-cultural patterns show that most societies have drinks specifically associated with religious rituals and drinks associated with secular rituals, including feasts (Bacon, Barry, and Child 1965; Bacon, Barry, Child, and Snyder 1965; Child et al. 1965). Medicinal drinks are common as well. Worldwide, events frequently associated with drinking include rites of passage, thanksgiving offerings relating to crops and the harvest, house construction, work parties, dedications to gods or ancestors, elections of chiefs or transitions of leaders, and prestige feasts (Child et al. 1965; Hayden 2001; Tedlock 2002). Most ritual drinking activity outside of religious ritual or medicine is collective and often associated with the need to mobilize labor for community works. Ritual consumption may be apparent in structured or ceremonial deposits of drinking vessels (Hamilakis 1999:48). Finally, drinking vessels are common funerary items (for the deceased to use in the afterlife, for use as part of the funeral, or for use by mourners).

\section{Social Impact}

Drinking occasions may help maintain social cohesion or offer an outlet for competition (Day and Wilson 2004:59), providing an "avenue to the creation of prestige and social capital" (Dietler 2006:237) by generating social indebtedness through hospitality, hosting ceremonies, or underwriting feasts. Gaining and maintaining prestige may depend on the ability to produce beverages or obtain beverage ingredients (Child et al. 1965; Dietler 2006:237). Drinking is important to the construction and transformation of identities, as specific drinks and associated paraphernalia may reflect age, gender, class, lineage, religion, and regional or national identities (Dietler 2006:235). For example, among the Luo of Kenya,

categorical distinctions between men and women, between elders and younger men, and between kinship groups are signaled at feasts by spatial criteria (i.e., who sits where and with whom), temporal distinctions (e.g., the order of serving), by different types of drinking vessels and practices, and by different types of beer and food [Dietler 2001:88].

Drinking rituals can thus involve highly standardized behaviors, including seating, placement of vessels, ways to hold vessels, and order of drinking (Bott 1987). Drinking etiquette involves authoritative information about correct behavior, with individuals having varied access to appropriate knowledge about manners, which are often performed in public and closely scrutinized by both outsiders and practitioners (Elias 1994; Wright 2004:90-91).

However, etiquette also provides a means for challenging power structures and delegitimizing authorities (Wright 2004:90). The adoption of new forms of drink can weaken established power structures and escalate social competition in the society, and the adoption of foreign drinking customs and paraphernalia can symbolically differentiate groups within a society or create a symbolic link with the emulated group (Dietler 1990:376-377; see also Bunimovitz and Greenberg 2004). Drinking customs may help institutionalize status differences within a group, promote solidarity, and serve as a means of mobilizing labor (Dietler 1990). But drinking parties are not always about solidarity, as they can "incorporate elements of exploitation, severe competition, masked coercion and violence and, 
subsequently, resistance" (Hamilakis 1999:49). A decline in factional competition may cause a decline in the need for feasts and drinking events, and drinking may become associated with an elite lifestyle and exclusivity instead (Hamilakis 1999:49; LeCount 1999). Colonizers often used drink as a tool for engaging the colonized, particularly in negotiations, though later interactions often involved forbidding the drink to the colonized (Heath 2000:92). Disruption in access to drinks or drinking paraphernalia may lead to internal revolt (Arnold 1999:80). Brenda Bowser's (2000) important ethnoarchaeological research in Ecuador emphasizes how even within the household, drinking activities can impact political alliances: guests paying formal or informal visits are served chicha in bowls with decorations that signify the household's political and factional allegiances.

Archaeological discussions of drinking focus largely on alcoholic beverages (Arnold 1999; Dietler 1990, 2006; Hamilakis 1999; Jennings et al. 2005; Joffe 1998; Smith 2008). However, archaeologists have also examined the consumption of stimulant drinks as well, including coffee, tea, cacao, and the varieties of holly drinks found in North and South America (Coe and Coe 2007; Joyce and Henderson 2010; McNeil 2006; Merrill 1979; Smith et al. 2003). While scholarship in the Southwest/Northwest and Mesoamerica has largely focused on the drinks themselves, some attention has also been paid to the drinking vessels and paraphernalia (Crown and Hurst 2009; Crown et al. 2015; Joyce and Henderson 2010; Mathiowetz 2011; Powis et al. 2002; Putsavage 2008). Recent research suggests that both cacao (Theobroma cacao) and holly (Ilex vomitoria) were imported drink ingredients in the Southwest/Northwest (Crown and Hurst 2009; Crown et al. 2015; Washburn et al. 2011, 2013).

\section{Ethnographic Evidence}

Groups living today in the Southwest/Northwest provide a context for examining drinking practices in the past (Havard 1896; La Barre 1938; Waddell 1980), while recognizing that drinks, recipes, vessels, and associated practices likely changed over time. In their study of feasting and alcohol production and consumption among the
Tohono O'odham of southern Arizona and the Rarámuri of southwestern Chihuahua, Merrill and Sprehn (2002) found significant differences, notably in women's roles in preparing the beverages (women do not participate in fermenting saguaro wine, while only women prepare maize beer among the Rarámuri), in the extent of networks involved in preparing and consuming the beverages (extensive villages among the Tohono O'odham, only local communities among the Rarámuri), the purpose of drinking (for rain among the Tohono O'odham, for many purposes among the Rarámuri), and the symbolic meaning of the beverages (rain among the Tohono O'odham, and many meanings among the Rarámuri). Importantly, alcohol consumption among the Tohono O'odham is limited to a specific set of rituals held during a restricted part of the year (see also Waddell 1980:8), while the Rarámuri consume alcohol in conjunction with work parties and fiestas throughout the year. Waddell argues for a similar contrast with Athabaskan groups in the Southwest/Northwest: that they used beverages to "engage social and kinship relations rather than to invoke rain for their fields" (1980:3). Driver (1969:110) argues for the utilization of fermented drinks among the Zuni, and perhaps the Keresan Pueblos prior to contact, with use restricted to social and secular occasions rather than farming ritual.

Whatever the status of alcoholic beverages among the Pueblos, there is no question that drinking was an important component of many Pueblo rituals. The Green Corn Dance included drinks brought from a distance and consumed by Koshare dancers for purification (Bandelier and Hewett 1937:50). Parsons (1939:50) notes a number of rituals that entailed drinking, including the One Spring Time ceremony performed by kiva societies, which involved a mountain retreat and consumption of a drink made by mixing ground herbs with water imbibed from a gourd. She (1939:374, 377, 414, 587, 686-687, 689) describes several rituals involving liquids, sometimes medicines, placed in medicine bowls and then aspersed to all participants or administered by shell. A ceremony of purification at Cochiti involved a shaman giving participants water from a medicine bowl (Bunzel 1932:531 n. 81). Ortiz describes a 
sweet drink of fermented grain consumed as part of the "bringing the buds to life" ceremony among the Eastern Pueblos (1969:99-100, 114), when the winter moiety transfers power to the summer moiety. The Zuni drank a number of concoctions, including a tea made from a plant of the mustard family and consumed only by members of the Galaxy Fraternity in ceremonial chambers (Stevenson 1915:99). Drinks are consumed as part of rituals to bring rain or snow but also for purification (Waddell 1980:24), as part of curing ceremonies and rites of passage (including for children; Ortiz 1969:261).

Common Pueblo drinking containers described in these accounts include ceramic medicine bowls, gourd dippers, and shells (particularly abalone shells). Gourds and shells were likely traditional forms with a long history of use. The rituals include a leader, and some include ranking of who drinks, when, and out of what vessel (Parsons 1939:689). Some drinks are associated with specific sodalities and consumed in private, ceremonial locations.

After contact, the Spanish colonists of what is now New Mexico controlled access to cacao and used it as an important tool in gastropolitics. Mission supply trains brought chocolate and majolica drinking cups to the Spanish missions every three years, partly for use in their infirmaries (Snow 2005) but also for serving native individuals of high rank. During the Pueblo Revolt, chocolate was one of the commodities taken from the Spanish and hidden by the Pueblos (Cabezon et al. 2009:428). Chocolate drinks were then used in negotiating with the Pueblos upon the Spanish reconquest in 1692 (Kessell and Hendricks 1992:407). The Spanish were likely following a long history of using drinks in sustaining social differentiation and conducting political negotiation.

\section{Archaeological Evidence in Chaco}

I turn now to evidence from Chaco Canyon, New Mexico, including the sequence of forms, quantity, and contexts of drinking vessels. I interpret specific forms as drinking vessels based on their physical attributes, analogies with traditional vessel use in portions of the Southwest/Northwest, and evidence of contents where available. There are no known images of drinking in rock art or kiva murals or on ceramics themselves (Kelley Hays-Gilpin, personal communication 2017). I also propose that these vessels were used at least sometimes for serving, mixing, pouring, and/or imbibing drinks in social settings, rather than primarily in private, making them visible to others. I employ the scholarship reviewed above to interpret the record of drinking forms, particularly that shared forms indicate a common tradition, while differences in form, color, and the presence of designs reflect identity negotiation. Where everyone shared the same basic form and vessels differ only in color or design, such negotiation likely involved the individual, but when segments of the larger population used distinctive forms, that negotiation shifted to the level of the group, suggesting competition (Berg 2007:249). Evidence for the nature of the individuals or groups associated with particular vessel forms comes from discard contexts. Finally, based on worldwide patterning (Bacon 1976; Bacon, Barry, Child, and Snyder 1965; Dietler 1990:364), men typically obtained the exotic ingredients for and consumed special drinks, while women typically prepared such special drinks, with their consumption (and that by children) of those drinks more open to question.

Drinking vessels in the Chaco area largely follow the worldwide patterns described above (Figure 1). The earliest Chaco drinking vessel forms were almost certainly gourds. While gourds do not preserve well, they are easily cultivated, and the form can be manipulated during growth to achieve specific shapes. Fragments of gourd canteens were recovered in Chaco (Judd 1954:159). Unfortunately, we do not know whether gourds used for drinking were decorated (as calabashes used for drinking cacao were historically among the Maya [Tedlock 2002:171] and gourds used for rattles were in Chaco [Judd 1954:279]), or whether they remained important drinking vessels, so I focus on the vessels we know to have been used.

In the $\mathrm{AD} 500 \mathrm{~s}$, several of the earliest ceramic forms in Chaco may be skeuomorphs of gourd vessels, including decorated neckless jars, known as seed jars or tecomates, at least some of which were likely used for drinking, perhaps 


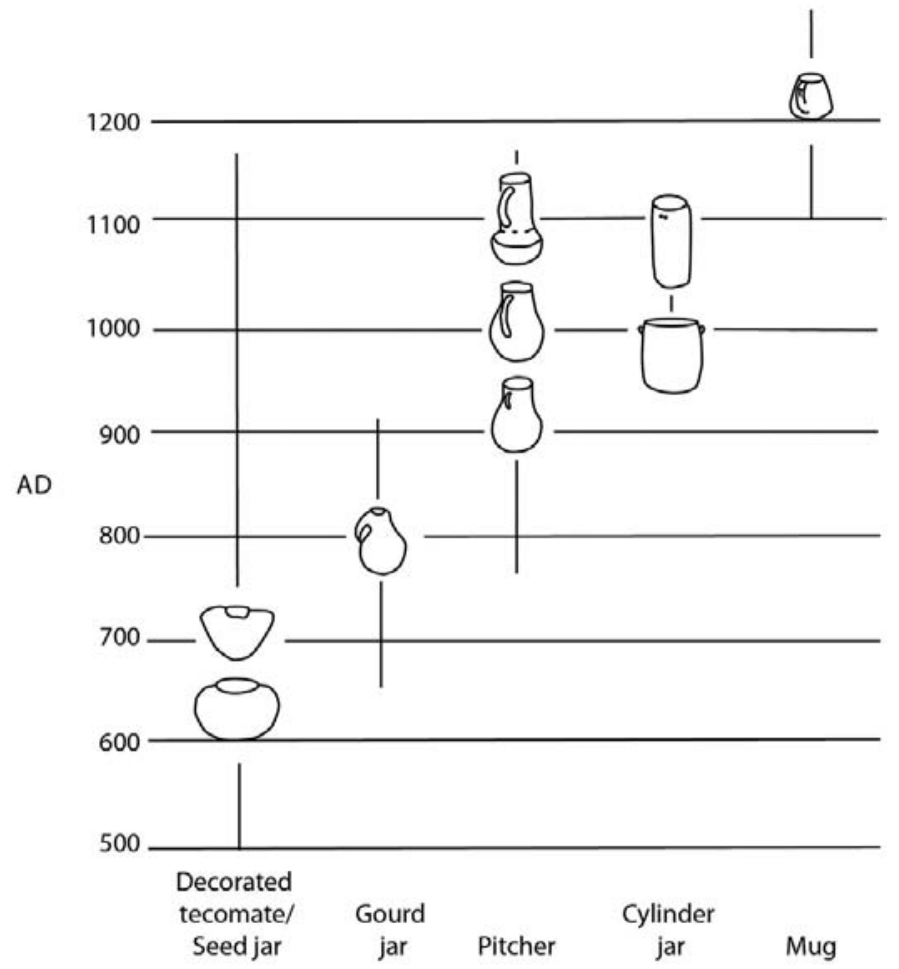

Figure 1. Forms of ceramic drinking vessels found in Chaco Canyon (figure drawn by Jill Jordan).

with straws. In Mesoamerica, Clark and Blake (1994:25; see also Houston 2014:65) indicate that the first ceramics (particularly tecomates dating to ca. $1900 \mathrm{BC}$ ) mimic gourd forms. They (1994:26) argue that producing the same form in ceramics enhanced the vessel's value without tampering with the social conventions of the form. Houston argues that these ceramic gourd skeuomorphs were adopted because they served as "socially marked contrasts with everyday receptacles of perishable materials" in community feasts (2014:66). He suggests that skeuomorphy is triggered at moments of change, in this case, new feasting activity. As to the acceptance of this innovation, Henrich (2010:103, 108) argues that it is the opportunity to imitate a successful or influential person who adopts an innovation that encourages acceptance of that innovation rather than cost-benefit analysis or mechanical performance characteristics. Whether the same holds true for Chaco is not known, but early tecomates could signal the initial use of ceramic drinking vessels to differentiate some individuals from those using gourds, perhaps also in the context of community feasts.

Chacoan potters began crafting ceramic vessels with the shape of entire gourds around AD 650 (Toll and McKenna 1997). With their asymmetrical shape and small orifice, these gourd effigies required skill to create and were suitable for fewer uses than tecomates; they are not common in Chaco. No testing has been done to determine what liquids were consumed from them. There is nothing unusual about their discard; one was found with a burial in Chaco (Pepper 1920:Figure 47b). As with the tecomates, the use of ceramic gourd effigies suggests an effort by some individuals to differentiate themselves from people drinking from natural gourds. So at least by AD 650, drinking had become an arena for differentiation in Chaco Canyon.

Pitchers are the most common drinking vessel in Chaco Canyon. The name is somewhat of a misnomer; the vessels are closest to steins in shape and lack a pouring lip. The pitcher appears first in grayware ceramics (Toll and 


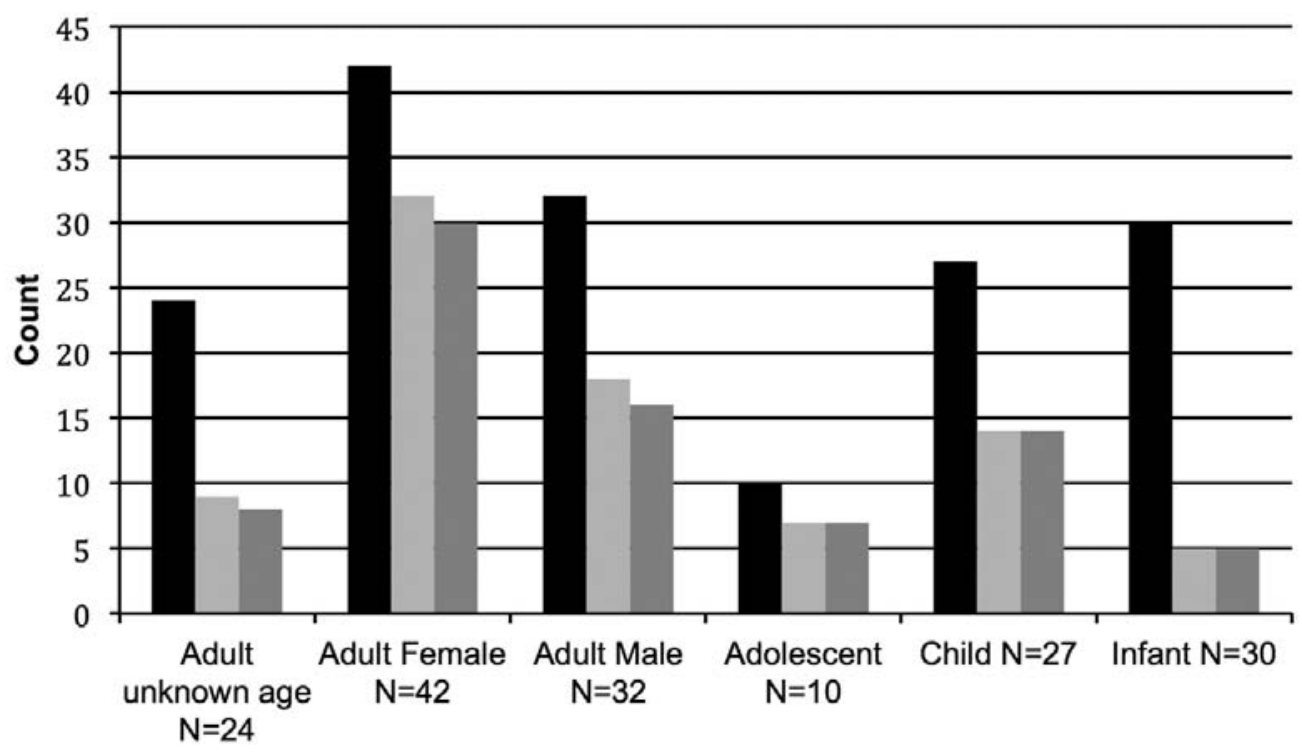

Burial Age and Sex

\section{- Number of Burials Number of Drinking Vessels Number of Pitchers}

Figure 2. Frequency of ceramic drinking vessels and pitchers in burials in Chaco Canyon (data from Akins 1986).

McKenna 1997:55) and rarely with black paint designs probably around AD 650 (Lister and Lister 1978:18-19). Decorated pitchers became increasingly common after AD 700 and remained in use into the AD 1100s (Toll and McKenna 1997:Table 2.15), although the shape evolved over time. The later decorated forms have residue indicative of cacao or holly (Crown et al. 2015); plainware forms are sometimes sooted and were probably used for cooking. By the AD 800s, the pitcher was likely the primary drinking vessel for individuals in Chaco. Novice potters made pitchers more than any other form, although bowls would have been easier to make (Crown 2016a:80). While most pitchers found in Chaco are Cibola White Ware, a possibly local product, Chacoans also imported some pitchers, including redware; drinking from a redware pitcher would obviously differentiate an individual.

Archaeologists have recovered pitchers in varied contexts, including kivas, and pitchers were second only to bowls as mortuary ceramics, suggesting the importance of pitchers as personal objects and in mortuary ritual (Mills 1993:306). Analysis of Chaco mortuary data indicates that pitchers occur more often with adults than with children (Figure 2) and more often in Great House burials than in small site burials (Akins 1986:94, 97) during the period from about AD 1030 to 1150. They are common burial accompaniments with both male and female adults throughout the sequence. In addition, Chacoans employed pitchers in two types of ceremonial or performative depositional practices in Pueblo Bonito. The first type involved the placement of groups of vessels directly in front of doors and on thresholds, probably as a symbolic barrier blocking passage through the door (Figure 3). For instance, 30 vessels blocked the threshold from Room 28 to the adjacent Room 51a on the Room 28 side. These vessels so thoroughly prevent easy passage that they must represent a type of closure for those doorways. Among the Pueblos ethnographically, outsiders were not allowed in rooms where sacred things were stored; at Zuni, for example, "if any one crosses the threshold he is 'caught' and must be initiated into the group" or whipped and forced to make payments (Bunzel 1932:502). The vessels may have served as a warning that crossing the threshold into Room 28 was taboo. Although in a practical sense, passage was blocked by 


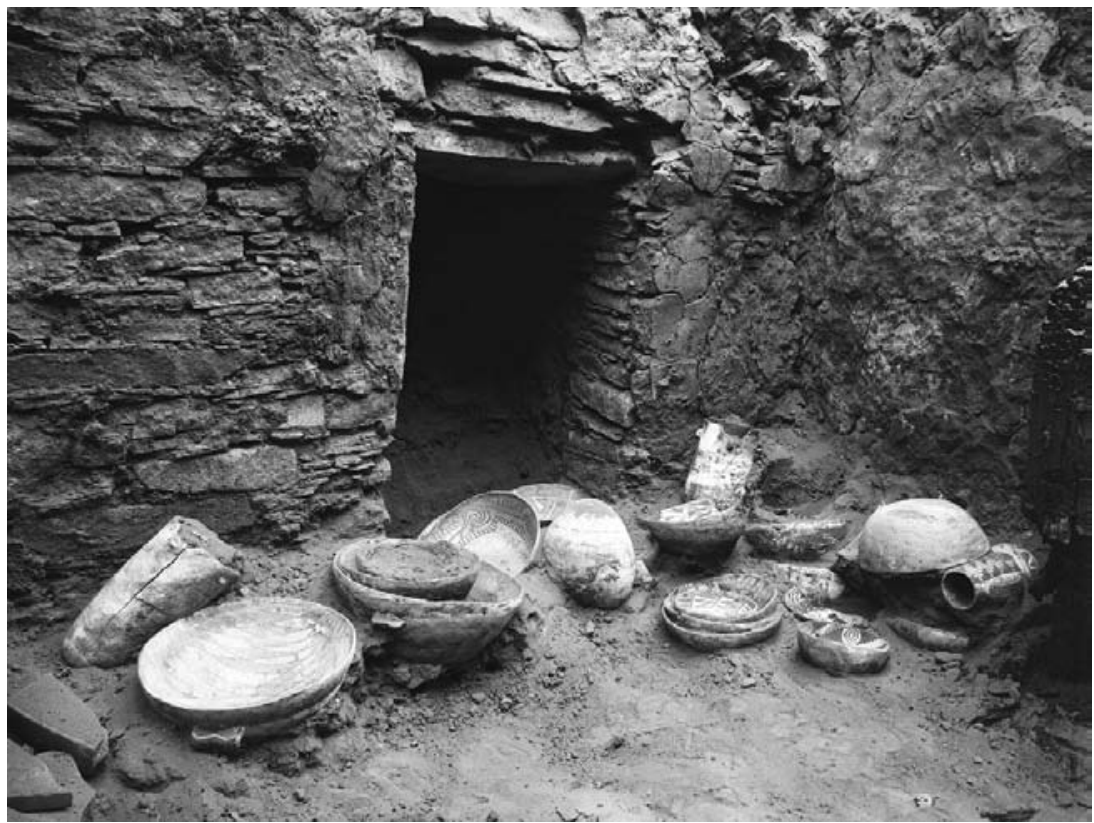

Figure 3. Some of the vessels in Pueblo Bonito Room 28 blocking the northeastern doorway to Room 51a as found in 1896; a second layer of vessels was located beneath this one (Image \#411882 [HEE 107], courtesy of the American Museum of Natural History Library).

breakable/movable objects, Chacoans might have perceived the objects themselves as symbolic guardians of those passages. The second type of depositional practice involved termination or deanimation by smashing or burning vessels, which removed them from circulation, deactivated their power, and protected individuals from contact with them (Lucero 2008:192; Mills and Ferguson 2008). Discard of groups of pitchers, some heavily burned, in some rooms in Pueblo Bonito (including 20 in Room 28 and 12 in Room 99 [Pepper 1920:312]) indicates deanimation of these vessels.

Potters began crafting Chacoan cylinder jars with Red Mesa Black-on-white designs that suggest manufacture in the AD 900s. ${ }^{1}$ Cylinder jars also have the residue of caffeinated plants interpreted as cacao or holly (Crown et al. 2015). Early cylinder jars are large and wide (average orifice diameter of $15.1 \mathrm{~cm}){ }^{2}$ The three known Red Mesa Black-on-white jars lack provenience. However, they appear to be Cibola White Ware and could have come from Chaco Canyon. These vessels appear too large to have been personal drinking vessels and likely served as communal drinking/serving vessels, with individuals passing the vessel around the group (Hamilakis 2008:11) or receiving their portion from ladles, gourd cups, or shells or through straws. They would have required two hands to hold. In this manner, they differed from pitchers not only in shape but also in consumption patterns and the etiquette that governed their use. The low number of vessels suggests that drinking was an exclusive activity, perhaps associated with religious rituals; it may also indicate that the drink was scarce. As Douglas (1987:11) suggested, when drink is scarce, social control is high; in such settings, drinking rituals clarify social roles and strata. As noted above, the large size might have suggested abundance, but the opaque walls might have disguised the actual quantity of drink.

Beginning about AD 1030, when Gallup Black-on-white became the dominant decorative style, potters began crafting narrower cylinder jars that could be held in one hand (average orifice diameter of $9.8 \mathrm{~cm}$; Figure 4). Some potters fashioned these in sets of two to four vessels with identical shapes and lug configurations but sometimes different designs (Figure 5). The ability of potters to create sets of identical forms indicates a level of standardization 


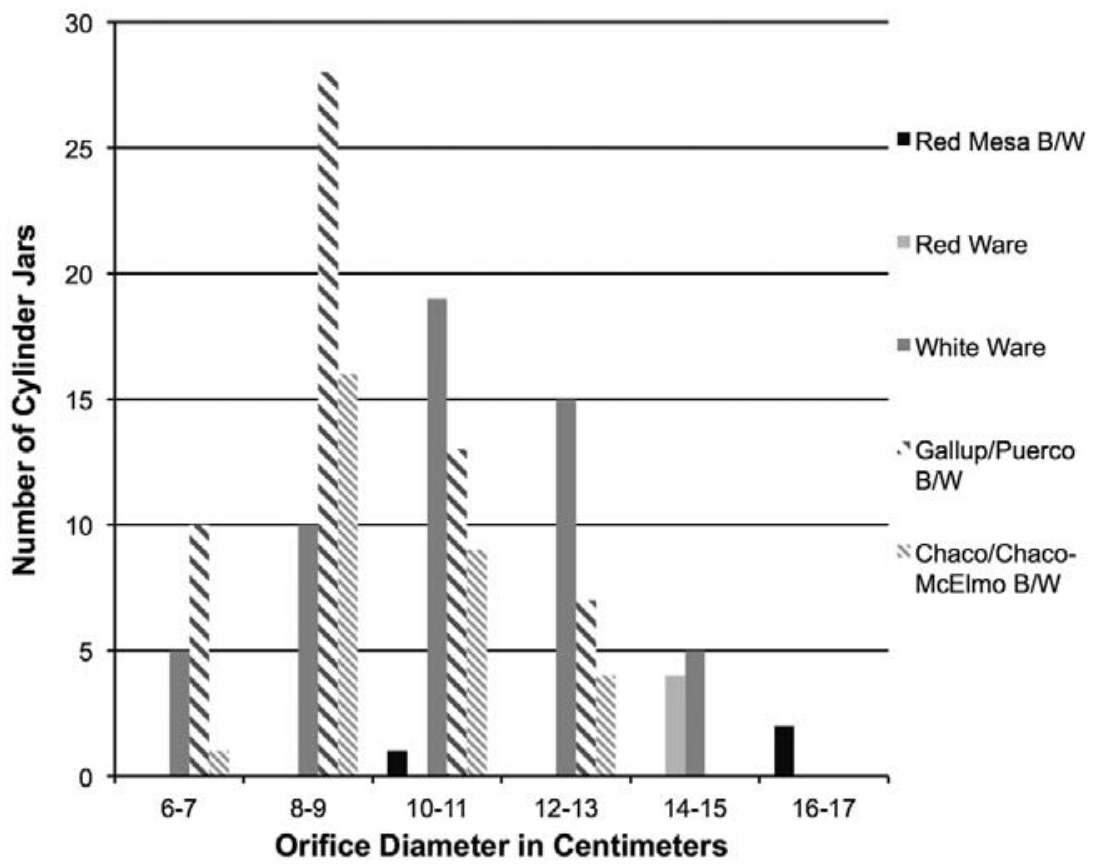

Figure 4. Changes in cylinder jar orifice diameters through time, showing the earliest (Red Mesa Black-on-white) vessels having the largest orifices and later types exhibiting smaller orifices.

not recognized in other Chacoan ceramics (Toll 1990:284). Interestingly, sets of two to four vessels also characterize drinking patterns in prehispanic Bolivia, where drinking was part of social competition (Anderson 2009:186). In that area today, pairs of drinking cups are used in feasting events in which the host drinks from one cup and passes the other to each guest in turn (Anderson 2009:186). The pairing of vessels was also a part of drinking rituals in Late Bronze Age Mycenaean Greece (Stockhammer 2012:19; Wright 2004), where the sets indicate "the emergence of standards of taste and a burgeoning demand for commodities . . . that could be used in displays of status" (Wright 2004:99-100). Chacoan sets might have been used to froth the drinks, employing a method used by both the Maya and the Aztec (Coe and Coe 2007:48, 86) that involved pouring the drink from a jar held at chest height into a jar set on the ground. If true, public preparation of the drinks may have become an important performative part of the ritual. Two double-cylinder jars (Post 1989) emphasize the importance of pairing/twinning for these vessels. Importantly, the shift to the use of drinking sets suggests the presence of a shared social etiquette surrounding the consumption of drinks, regardless of the specifics.

Based on visible aplastic inclusions, slip, paint composition, and designs, most eleventhcentury cylinder jars appear to be Cibola White Ware, possibly made in Chaco Canyon. The cylinder jar is not a difficult form to create, although creating identical sets requires more skill. Yet the varied quality of the finished products indicates that production was not restricted to skilled potters. An instrumental neutron activation analysis of 12 cylinder jars showed compositional homogeneity, suggesting that they were all manufactured in the same area (Neitzel and Bishop 1990). There are intrusive cylinder jars as well: at least four decorated jars are Chuska White Ware from the Chuska Slope west of Chaco, four identical Showlow Red jars came from southwest of the canyon, and a Flagstaff Black-on-white jar and a Black Mesa Black-onwhite jar came from north-central Arizona.

It is possible that potters produced a new set of vessels annually and retired old sets, so that only a few vessels were in use in any one 


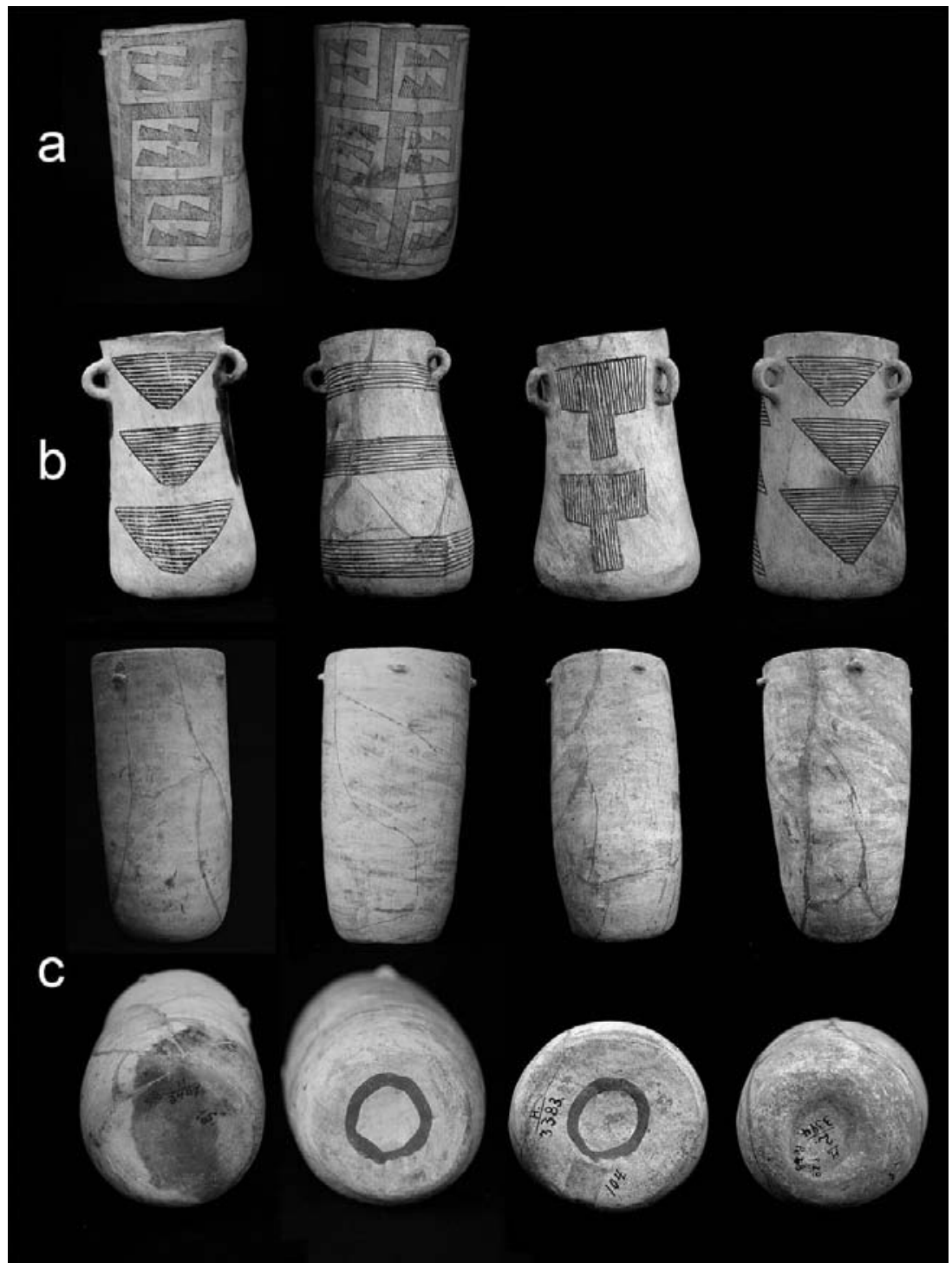

Figure 5. Cylinder jar sets from Pueblo Bonito, not to scale. (a) Gallup Black-on-white vessels (from left to right): A336496, H3392 (height $20.8 \mathrm{~cm}$ ); (b) Gallup Black-on-white vessels: 52053, H3400, H3253, H3237 (height $17.7 \mathrm{~cm}$ ); (c) Profile and base with maker's marks of Cibola White Ware vessels: H3407, 52116, H3383, H3394 (height 26.4 cm). (A336496 courtesy of the Department of Anthropology, Smithsonian Institution; H3392, H3400, H3253, H3237, H3407, H3383, and H3394 courtesy of the Division of Anthropology, American Museum of Natural History; 52053 and 52116 courtesy of the National Museum of the American Indian, Smithsonian Institution. Figure created by Drew Wills.)

year. Otherwise, the roughly 200 cylinder jars found in Chaco Canyon suggest large-scale consumption events. Fifty-four percent of these jars exhibit moderate to heavy external use-wear, and at least $23 \%$ show reslipping/repainting layers interpreted as renewal over time (Crown and Wills 2003), so at least some were used on multiple occasions. If all vessels were used at once, the number of participants would have been quite large. But the designs are not all contemporaneous, suggesting that more jars were put into use over time. The presence of jars of Showlow Red, Black Mesa Black-on-white, and Chuska White Ware supports the idea that drinking 


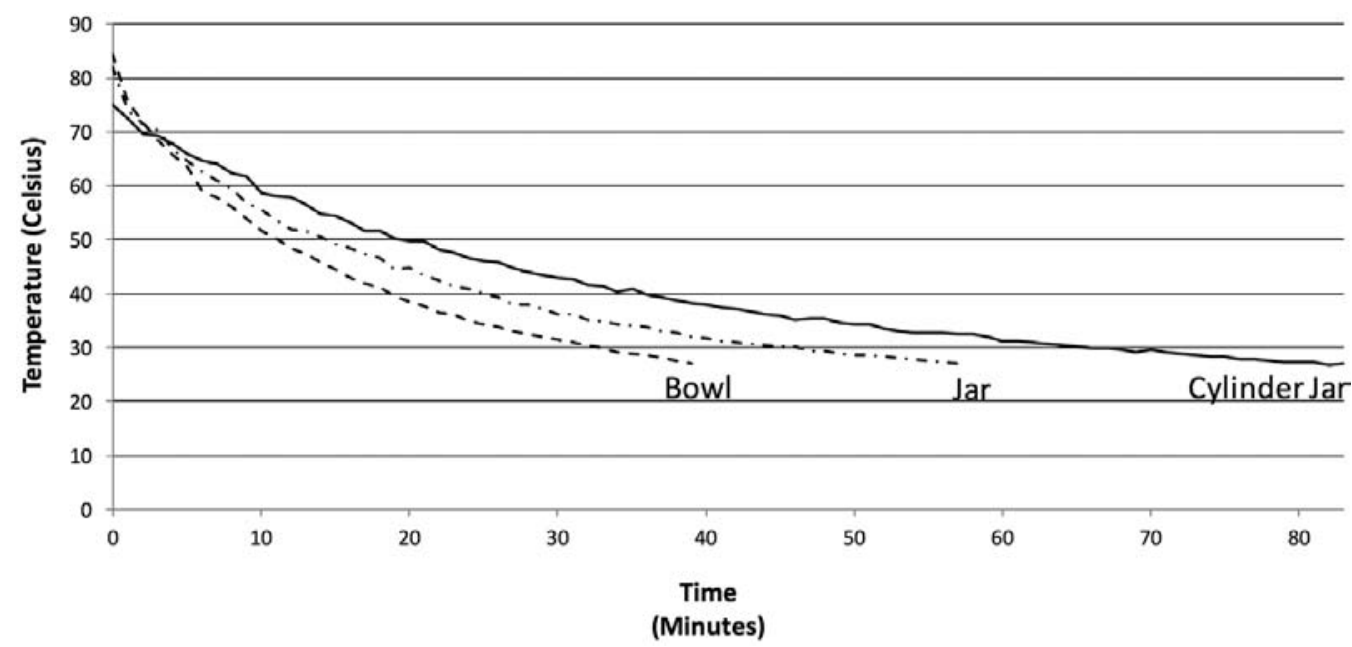

Figure 6. Results of a heat retention experiment on three ceramic vessels with identical volume (1,000 cc) but different shapes, showing change in temperature over time for $237 \mathrm{cc}$ of boiling water to cool to room temperature (experiment performed and figure created by Jill Jordan).

events included participants from outside the canyon. Toll suggested that "cylinder jars were produced by communities of the Chaco system and were placed in its most significant structure as expressions of participation" (1990:296), with the number of jars representing the number of participating communities in the system at AD 1100.

Cylinder jars are often found in association with sandstone discs believed to be jar lids (Pepper 1920). The association of cylinder jars with sandstone jar lids suggests the possibility that Chacoans preferred their drinks hot, with the lids used to retain heat. Experimental work comparing heat retention in cylinder jars, jars with necks, and bowls with identical volumes confirms that the cylinder form has superior heat retention (Figure 6). Eighty-six percent of the cylinder vessels have lugs (small loops or knobs attached to the side of the vessel) of various shapes and numbers. It is possible that the lugs were used to tie down the jar lids, and, indeed, one jar has an inner lip positioned to accept a jar lid. Alternatively, string threaded through the lugs (or, for six vessels, holes) might have been used for suspension of the jars. But many of the lugs are completely appended to the vessel wall, so that nothing could be attached to them, and some lugs are too fragile for attachments. Most lugs show no wear or polish suggestive of use (Washburn 1980:79-80). Lugs may have been purely decorative or perhaps used to attach ornaments or feathers to the pots.

The cylinder jar shape, distinct in any Chaco assemblage, was likely made for public display and to be recognized at a distance. At times when cacao or holly was scarce, holding a cylinder jar might have reminded viewers of this exotic luxury drink (van der Veen 2003). While the decorated jars are mostly within the Gallup/Chaco Black-on-white canon, the variety of designs, shape profiles, and lug shapes suggest the importance of differentiating the drinkers (Hamilakis 2008:11). About one-third of the vessels were plain white when found but may have once been decorated with bright postfiring pigment designs on stucco, based on the finding of plaster still adhering to some and the discovery of Pueblo Bonito sherds covered with plaster colored with powdered turquoise or hematite (Crown and Wills 2003).

Cylinder jar sherds are difficult to differentiate from pitcher sherds, so we do not know exactly how many broken cylinder jars were discarded in trash middens, but some unquestionably were (Crown 2016b). All but five of the roughly 200 cylinder vessels with known proveniences were recovered in Chaco Canyon, and around 175 come from Pueblo Bonito (Table 1; Figure 7). None were recovered from kivas. While 20 come 
Table 1. Cylinder Jar Proveniences.

\begin{tabular}{|c|c|}
\hline Site & Number of Cylinder Jars \\
\hline Pueblo del Arroyo & 7 \\
\hline Pueblo Alto & $1-3$ \\
\hline 29SJ 1360 & 1 \\
\hline 29SJ 633 & 1 \\
\hline Bis sa'ani & 1 \\
\hline LA59497 & 1 double jar \\
\hline Manuelito & 1 \\
\hline Piedra District & 1 \\
\hline Navajo Reservoir & 1 \\
\hline Black Mesa & 1 \\
\hline Unprovenienced & 3 \\
\hline \multicolumn{2}{|l|}{ Pueblo Bonito room } \\
\hline 28 & 112 \\
\hline 32 & 5 \\
\hline 33 & 2 \\
\hline 39B & 23 \\
\hline 52 & 1 \\
\hline 53 & 1 \\
\hline $53 / 56^{\mathrm{a}}$ & 2-12 (1 double jar) \\
\hline 65 & 1 \\
\hline 72 & 1 \\
\hline 136 & 1 \\
\hline 163 & 1 \\
\hline 251 & 1 \\
\hline 309 & 1 \\
\hline 320 & 3 \\
\hline 326 & 1 \\
\hline 329 & 6 \\
\hline 330 & 6 \\
\hline Total & 199 \\
\hline
\end{tabular}

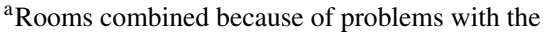
excavations.

from rooms that have burials, only one was directly associated with an individual burial, an adult female (Skeleton \#5/H3663 in Room 33, 40-50 years of age [Marden 2011:566]), with the Puerco Black-on-white cylinder jar (H3637) found resting on her occipital (Akins 1986).

Cylinder jars primarily come from the same two types of ceremonial or performative deposits described above for pitchers: placement blocking doorways (possibly guardians, as described above) and deanimation by smashing or burning. In some Pueblo Bonito rooms, individuals terminated cylinder jars by smashing them on a surface (10 were smashed on the upper-story floor of Room 28). The most extreme cylinder jar termination consists of 102 vessels executed in Room 28 in Pueblo Bonito. Recent reexcavation of the room shows that around AD 1100, individ- uals placed 99 of the jars on a shelf in this room, sprinkled them with turquoise and shell beads, and lit a large fire under the shelf. The room doors were sealed, some with vessels blocking them. The room burned and collapsed over the jars. The cylinder jars and the room in which they were housed probably required deanimation and destruction when the jars were taken out of circulation. The 19 vessels found in burial rooms but not associated with individuals might have been general offerings to the group or room or terminated through burial. The discard patterns of cylinder jars thus suggest that they were not the property of individuals or households (i.e., a domestic, residential unit). Instead, they likely belonged to a corporate group that stored the vessels in Room 28.

By the time Room 28 was used for storing the cylinder jars, it was an underground room that had a stairway up to the West Court of Pueblo Bonito. As Mills (2008:105) notes, the storage of most cylinder jars adjacent to the West Court suggests their use in that space. Given the number of jars and the proximity to this open area, the consumption practices associated with cylinder jars probably involved ceremonial processions there, patterning seen in other parts of the world (Knappett 2011:163).

The presence of cylinder jars at the same time that pitchers were in use indicates intensified drinking activity at Pueblo Bonito, with feasts or rituals surrounding drinking becoming more common there. In this setting, having such visually distinctive drinking forms may have been an important means of differentiation. Drinking activity may have become competitive either within Pueblo Bonito or among the Great Houses within the canyon, with factions vying for followers. Consumption involving the cylinder jars was centered on Pueblo Bonito and was apparently successful in drawing participants from a distance for some decades in the late AD 1000s. The burial of an adult female with a cylinder jar suggests that the drinking events involved both women and men. The dramatic termination of the cylinder jars around AD 1100 indicates an abrupt end to their use in ritual drinking. While independent evidence suggests the destruction of Room 28 around AD 1100, one Chaco-McElmo Black-on-white and one Nava Black-on-white 


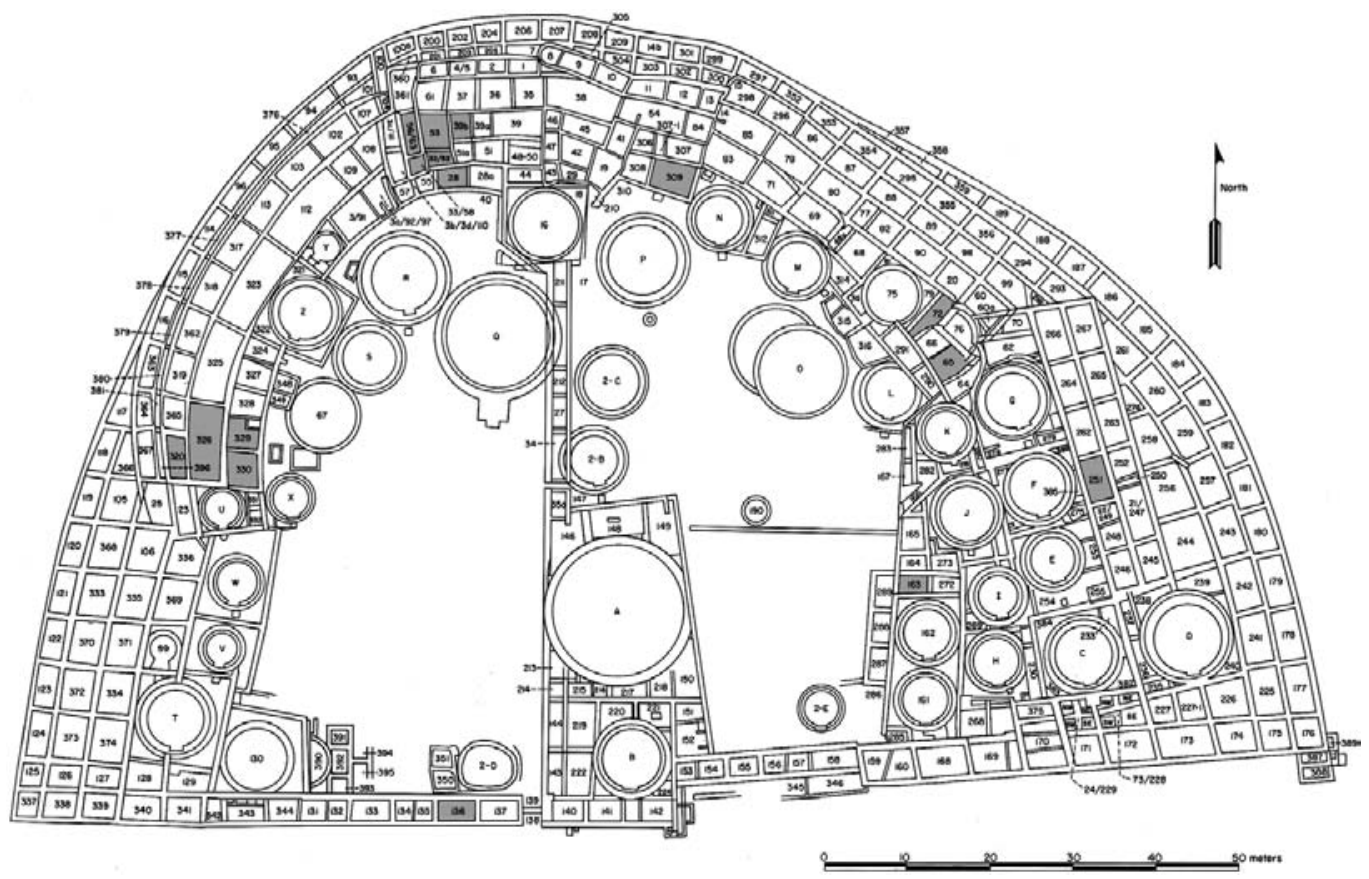

Figure 7. Locations of cylinder jars recovered in Pueblo Bonito rooms, indicated by gray shading; Room 28 is located at the northern edge of the West Court (figure created by Drew Wills).

are the latest vessels there, dating to AD 11001275 , confirming an end to vessel production in the first years of the twelfth century.

As distinctive as cylinder jars were, they were neither widely traded prestige items nor widely emulated or copied. A few potters at distant villages created cylinder jars, but based on the relative absence of cylinder jars outside of Chaco Canyon, almost all of those vessels were then brought to Pueblo Bonito rather than kept locally. So few Chacoan cylinder jars exist outside of Pueblo Bonito that there must have been control over their creation and use (see also Toll 1990:296).

This patterning contrasts with Maya practices. At feasts among the Classic Maya (AD 250900 ), elites provided cacao drinks to guests and then gifted the drinking vessels, cylinder jars with elaborately painted scenes (Reents-Budet 2006:222). Both drink and container had value, established social ties, and affirmed social distinction. In contrast, outsiders brought cylinder jars to Pueblo Bonito, where they remained. Perhaps gifting the vessels provided entrée for these outsiders. Even the disintegration of the
Chaco system did not lead to emulation elsewhere. Indeed, the termination of the cylinder jars appears to have been accompanied by the complete rejection of this form. The only known cylinder jar that postdates the destruction of Room 28 is a recently discovered Tusayan Polychrome (dated AD 1125-1290) from a site in northeastern Arizona (Kelley Hays-Gilpin, personal communication 2017).

Mugs appear in Chaco at about the time that cylinder jars disappear. The mugs are small, handled vessels about the size of a modern coffee mug but with a smaller orifice than base. These personal drinking vessels continue the pattern of increasingly smaller drinking vessels over time at Pueblo Bonito. There are a few Chaco-McElmo Black-on-white mugs (AD 1100-1150) and a possibly locally produced version of McElmo Black-on-white, but other mugs found in Chaco were made in the Mesa Verde area. Several researchers have argued that such mugs developed from Chacoan square-shouldered pitchers (Bradley 1996; Judd 1954:203; Toll and McKenna 1997:68), as a replacement/alternative to pitchers. In the Mesa Verde area, Bradley 


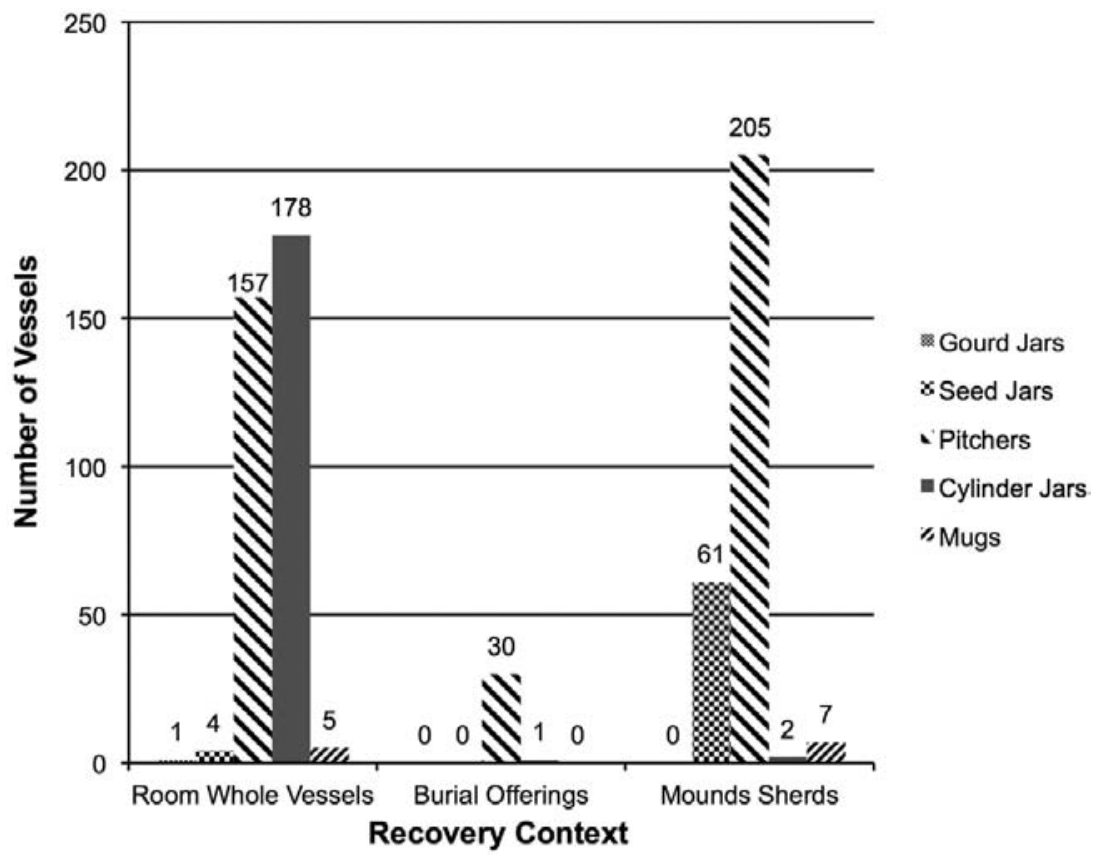

Figure 8. Drinking vessel forms found in three contexts in Pueblo Bonito, showing the high incidence of cylinder jars in rooms and pitchers in burials and trash mounds (data from Crown 2016b; Judd 1954; Pepper 1920); the pitcher sherd category may include cylinder jars, which are difficult to separate in sherd form.

argues that the mug form "did not serve as an everyday drinking vessel, but functioned primarily in ritual activities" (1996:248). But based on a large-scale study, Putsavage (2008) argues that mugs were personal serving vessels used for a variety of drinks. Residue analysis of mugs from Chaco, Aztec Ruins, and southwestern Colorado suggests that some had cacao residue (Crown et al. 2015). So, the consumption of caffeinated drinks did not cease with the termination of the cylinder jars. The five mugs from Pueblo Bonito occur in rooms without burials (Pepper 1920), but mugs do occur in burials at other Chacoan sites, as well as in trash mounds and as vessels blocking doorways (Figure 8).

The sequence of drinking vessels in Chaco Canyon shows interesting patterns when viewed in broader perspective. The early sequence of tecomates and gourd effigies is present widely in the northern US Southwest and millennia earlier in Mesoamerica. The pitcher form is common throughout the northern US Southwest but is considerably less common among groups to the south and was probably an innovation of the northern potters. And while the cylinder jar form may mimic Mesoamerican forms using a local technology, the mug is also a distinctly northern US Southwest form probably developed first in the northern San Juan region around AD 1050 (Putsavage 2008). Its presence in Chaco Canyon likely reflects the movement of people from northern San Juan into Chaco, together with their own drinking practices. Both pitchers and mugs were thus northern Ancestral Pueblo forms used as generalized personal drinking vessels. And while the cylinder jar was an addition to the existing vessel form repertoire at Pueblo Bonito, the mug was a replacement.

\section{Conclusions}

Drinking ritual impacted many aspects of life in Chaco: Exotic ingredients had to be obtained and prepared (perhaps in a performative manner); crafts had to be produced for serving drinks; and customs involving etiquette and hospitality had to be developed and practiced (Table 2). Exotic drink ingredients in Chaco likely included both cacao and holly. Brought from a distance, these were probably the highest-status drinks in Chaco Canyon after around AD 900. As argued elsewhere, "prestige drinks are economic 
Table 2. Production, Exchange, Consumption, and Discard of Vessel Forms in Chaco.

\begin{tabular}{lccccc}
\hline $\begin{array}{l}\text { Production, Use and } \\
\text { Context }\end{array}$ & Seed Jars & Gourd Jars & Pitchers & Cylinder Jars & Mugs \\
\hline $\begin{array}{l}\text { Produced in Chaco/Cibola } \\
\text { White Ware }\end{array}$ & Yes & Yes & Yes & Yes & $?$ \\
$\begin{array}{l}\text { Exchanged } \\
\text { Made in sets }\end{array}$ & Yes & Yes & Yes & Yes & Yes \\
Used with caffeinated & No & No & No & Yes & No \\
$\quad$ drinks & No & Not tested & Yes & Yes & Yes \\
Burials & Adult male & One unknown & All ages/ & Adult female & Adult males \\
& & age/gender & genders & and females \\
Kivas & Yes & $?$ & Yes & No & No \\
Deanimation deposits & $?$ & $?$ & Yes & Yes & Yes \\
Vessels blocking doors & No & No & Yes & & Yes \\
\hline
\end{tabular}

Sources: Data from Judd 1954; Marden 2011:Appendix I.d; Pepper 1920.

commodities that are easily divisible, cannot be stored for long periods and are not intended for accumulation, but for consumption" (Vencl 1994:313). But there were undoubtedly many kinds of drinks consumed in Chaco in a variety of ways. There were definite trends in the manner in which drinks were consumed, including drinking vessels made to be held by individuals (pitchers, later cylinder jars, and mugs) vs. communal vessels (perhaps tecomates and early cylinder jars), and these shifts are not entirely temporal in nature. With the changes in forms came changes in ritual practice and etiquette.

The pattern of vessel forms indicates an intensification of drinking practices in the eleventh century, with multiple forms of vessels signaling multiple recipes, ritual groups, social classes, or competitive factions. Following Dietler (1990), one group in Chaco may have adopted cacao and cylinder jars as a means of differentiating themselves and symbolically tying themselves to Mesoamerican groups that used cylinder vessels. However, if the cylinder vessel is an emulation of Mesoamerican vessels (Washburn 1980, 2008:299), it was the form and contents only that were emulated, rather than the designs. If the cylinder jars mimic Mesoamerican forms, their production using local materials and designs on a foreign shape may have helped to encourage acceptance of a new drinking ritual; at least one Spanish priest likely used a similar strategy in commissioning a Christian Communion chalice from a Jemez Pueblo potter to encourage acceptance of the foreign drinking ritual (Liebmann
2015:337). The cylinder jar may thus have been a consciously hybrid form, incorporating aspects of cacao consumption to the south with local craft traditions and thus combining the familiar with the exotic (mimesis and alterity [Taussig 1993]; see also Berg 2007:249). Both form and substance might have been viewed as holding positive sources of sacred power, in part through appropriation of that distinctive shape (Pugh 2009; Taussig 1993:19). Outside participants who brought cylinder jars made using their traditional wares and designs to Pueblo Bonito simultaneously announced their local identity and their new, shared identity with the ritual enacted at Pueblo Bonito.

Drinking of special concoctions generally occurs in the context of religious or secular rituals, including feasts, so these were likely contexts of consumption within Chaco as well. ${ }^{3}$ If all of the roughly 200 jars were used simultaneously, or even if each participant used a set of two vessels, the quantity of drink required and the labor needed to prepare it would have been quite high. Drinking rituals were likely practiced against a backdrop of competing claims to authority, because when there is no competition or factionalism, there is no need for such display. When leadership is contested, competitive events recruit followers and present a strong external image (Hayden 1995; LeCount 1999:242). In such contexts, providing drinks can be a route to status and power-particularly when exchanging drinks for work-but often only in the short-term (Dietler 1990:380). 
Providing drinks to participants from outside of Chaco undoubtedly would have created social debt (Dietler 1990; Henderson and Joyce 2006:141). It is perhaps no coincidence that the intensification of drinking activity occurred in Chaco when construction events were at their height (Lekson 1984). The termination of the cylinder jars and associated ritual occurred as this intense period of construction ended.

Consumption is inherently a process of "selfdefinition and collective identification" (Mullins 2011:135), and yet, while pitchers were relatively common mortuary items in Chaco Canyon, cylinder jars were not (and mugs were only in late contexts [Bradley 1996; Putsavage 2008]). Perhaps because cylinder jars belonged to a clan, sodality, or other corporate group within Pueblo Bonito, they were rarely used in mortuary practice and did not serve as identifiers of Chacoan identity in the afterlife. The almost complete lack of emulation of the cylinder jar form outside of Chaco may indicate either that the jars had negative connotations elsewhere or that Chacoans had tight control over the copying and circulation of these jars as symbolic capital, heightening their importance and value (Dietler 2001:86). In either circumstance, it seems surprising that nonChacoan potters occasionally made cylinder jars.

The concentrated termination of the cylinder jars indicates the end of their ritual use and perhaps the end of the competitive events in which they were used or the emigration or even expulsion of the group that used them (see Rabinowitz 2009). I suggest that whatever value and status the use of cylinder jars once held was gone but that the jars themselves still held power that had to be destroyed through respectful termination. Apparently, few wanted to be identified as believing in or belonging to the practices associated with cylinder jars once the jars were terminated. This was undoubtedly a time of upheaval as one form of drinking vessel and the behavior and rituals associated with it disappeared and an entirely different form of drinking vessel appeared, probably accompanied by changes in manners and standards of behavior (Elias 1994:79).

Changes in drinking vessels thus reflect changes in drinking practices, crafting, exchange patterns, religious and secular rituals, and the creation of avenues for differentiation in Chacoan society. From simple vessel forms widely shared over a large region, Chacoans adopted more narrowly regional forms, followed by a shape concentrated in use at Pueblo Bonito and finally a shape associated with northern groups. In the seven centuries represented by this sequence, the Chaco population rose and declined, new ideas were adopted and rejected, and standards and rituals associated with drinking transformed. I have argued here that the adoption of the cylinder jar form reflects intensification in drinking activity in Pueblo Bonito indicative of greater social differentiation, followed by the dramatic rejection and destruction of the paraphernalia associated with that ritual activity. Whether this rejection reflects the emigration of the segment of the population involved in the ritual, an end to factional competition at Pueblo Bonito, loss of access to some of the ingredients, or temporary abandonment of the site will require further study. Whatever the cause, the cylinder jar form was almost completely repudiated in the region. Individually owned and generalized drinking forms became the norm again until Pueblo Bonito was abandoned.

I conclude that in Chaco Canyon all drinking vessels except the cylinder jar belonged to individuals, providing opportunities for individual differentiation and distinction. But the cylinder jars indicate a different type of drinking activity at Pueblo Bonito that created social obligations among the participants and social differentiation between those who hosted and their guests, those who participated and those who were excluded. I suggest that the group that owned the ritual and maintained the cylinder jars created and enacted this performative arena, which in turn provided distinction for the group, the processional leaders, and those responsible for taking care of the jars (see Mills 2004:247). The jars may thus have helped establish hierarchy in Chaco, because one group had control over their use and the knowledge and power associated with it (Mills 2004:240). The cylinder jars' destruction and the return to the use of individually owned drinking vessels may signal the end of that particular hierarchy in the Chaco world.

Acknowledgments. This article is the result of over a decade of research on the Chacoan cylinder jars, funded by the 
University of New Mexico (RAC Grant) and National Endowment for the Humanities (RZ-51417-13). Aided by the individuals in parentheses, I examined cylinder jars at the American Museum of Natural History (Anibal Rodriguez, Lori Pendleton, David Hurst Thomas), the National Museum of Natural History (James Krakker, David Rosenthal, Bruce Smith), the National Museum of the American Indian (Lisa Anderson, Veronica Quiguango, Nathan Sowry), the Peabody Museum at Harvard (Patricia Capone, Susan Haskell, Steven LeBlanc), the Robert S. Peabody Museum at Andover (Bonnie Sousa), the Museum of New Mexico (Crystal Kieffer, Melissa Powell), the Museum of Man (Jennifer Stone, Judith Green Wells), the School of Advanced Research (Lisa Barrera), and the Chaco Culture National Historical Park (Wendy Bustard, Dabney Ford). I directed the Room 28 excavations with funding from the National Endowment for the Humanities (RZ-51417-13) and the National Geographic Society (9276-13), permitted by the National Park Service (ARPA Permit 13-CHCU-01). The article was enhanced by comments from Kelley Hays-Gilpin, Jill Jordan, Barbara Mills, Ben Nelson, Chip Wills, and three anonymous reviewers. Jill Jordan performed the heat retention study. Stephen Post provided information on the Black Hat cylinder vessel, and Kelley Hays-Gilpin provided information on the Tusayan Polychrome vessel. Jacque Kocer translated the abstract into Spanish.

Data Availability Statement. All vessels discussed in this study are housed in the museums listed in the acknowledgments.

\section{References Cited}

Akins, Nancy

1986 A Biocultural Approach to Human Burials from Chaco Canyon, New Mexico. Reports of the Chaco Center 9. National Park Service, Santa Fe, New Mexico. Anderson, Karen

2009 Tiwanaku Influence on Local Drinking Patterns in Cochabamba, Bolivia. In Drink, Power, and Society in the Andes, edited by Justin Jennings and Brenda J. Bowser, pp. 167-199. University of Florida Press, Gainesville.

Arnold, Bettina

1999 "Drinking the Feast": Alcohol and the Legitimation of Power in Celtic Europe. Cambridge Archaeological Journal 9:71-93.

Bacon, Margaret K.

1973 Cross-Cultural Studies of Drinking. In Alcoholism: Progress in Research and Treatment, edited by Peter G. Bourne and Ruth Fox, pp. 171-194. Academic Press, New York.

1976 Cross-Cultural Studies of Drinking: Integrated Drinking and Sex Differences in the Use of Alcoholic Beverages. In Cross-Cultural Approaches to the Study of Alcohol, edited by Michael W. Everett, Jack O. Waddell, and Dwight B. Heath, pp. 23-34. De Gruyter Mouton, Boston.

Bacon, Margaret K., Herbert Barry, III, and Irvin L. Child 1965 A Cross-Cultural Study of Drinking: II. Relations to Other Features of Culture. Quarterly Journal of Studies on Alcohol 3:29-48.
Bacon, Margaret K., Herbert Barry, III, Irvin L. Child, and Charles R. Snyder

1965 A Cross-Cultural Study of Drinking: V. Detailed Definitions and Data. Quarterly Journal of Studies on Alcohol 3:78-111.

Bandelier, Adolf, and Edgar Lee Hewett

1937 Indians of the Rio Grande Valley. University Press, Albuquerque, New Mexico.

Berg, Ina

2007 Meaning in the Making: The Potter's Wheel at Phylakopi, Melos (Greece). Journal of Anthropological Archaeology 26:234-252.

Blitz, John $\mathrm{H}$.

2015 Skeuomorphs, Pottery, and Technological Change. American Anthropologist 117:665-678.

Bott, Elizabeth

1987 The Kava Ceremonial as a Dream Structure. In Constructive Drinking: Perspectives on Drink from Anthropology, edited by Mary Douglas, pp. 182-204. Cambridge University Press, Cambridge.

Bowser, Brenda J.

2000 From Pottery to Politics: An Ethnoarchaeological Study of Political Factionalism, Ethnicity, and Domestic Pottery Style in the Ecuadorian Amazon. Journal of Archaeological Method and Theory 7:219-248.

Bradley, Bruce

1996 Pitchers to Mugs: Chacoan Revival at Sand Canyon Pueblo. Kiva 61:241-255.

Bunimovitz, Shlomo, and Raphael Greenberg

2004 Revealed in Their Cups: Syrian Drinking Customs in Intermediate Bronze Age Canaan. Bulletin of the American Schools of Oriental Research 334:19-31.

Bunzel, Ruth

1932 Introduction to Zuni Ceremonialism. Forty-Seventh Annual Report of the Bureau of American Ethnology, pp. 467-544. US Government Printing Office, Washington, DC.

Cabezon, Beatriz, Patricia Barriga, and Louis Evan Grivetti 2009 Blood, Conflict, and Faith: Chocolate in the Southeast and Southwest Borderlands, 1641-1833. In Chocolate: History, Culture and Heritage, edited by Louis Evan Grivetti and Howard Yana Shapiro, pp. 425-437. John Wiley and Sons, New York.

Child, Irvin L., Margaret K. Bacon, and Herbert Barry, III 1965 A Cross-Cultural Study of Drinking: I. Descriptive Measurements of Drinking Customs. Quarterly Journal of Studies on Alcohol 3:1-28.

Clark, John E., and Michael Blake

1994 The Power of Prestige: Competitive Generosity and the Emergence of Rank Societies in Lowland Mesoamerica. In Factional Competition and Political Development in the New World, edited by Elizabeth Brumfiel and John W. Fox, pp. 17-30. Cambridge University Press, Cambridge.

Coe, Sophie E., and Michael D. Coe

2007 The True History of Chocolate. Thames and Hudson, London.

Crown, Patricia L.

2016a Secrecy, Production Rights, and Practice in the Prehispanic American Southwest. In Knowledge in Motion: Constellations of Learning across Time and Place, edited by Andrew P. Roddick and Ann B. Stahl, pp. 67-96. University of Arizona Press, Tucson.

2016b Summary and Conclusions. In The Pueblo Bonito Mounds of Chaco Canyon, edited by Patricia L. Crown, 
pp. 213-237. University of New Mexico Press, Albuquerque.

Crown, Patricia L., Jiyan Gu, W. Jeffrey Hurst, Timothy J. Ward, Ardith D. Bravenec, Syed Ali, Laura Kebert, Marlaina Berch, Erin Redman, Patrick D. Lyons, Jamie Merewether, David A. Phillips, Lori S. Reed, and Kyle Woodson

2015 Ritual Drinks in the Pre-Hispanic US Southwest and Mexican Northwest. PNAS 112:11436-11442.

Crown, Patricia L., and W. Jeffrey Hurst

2009 Evidence of Cacao Use in the Prehispanic American Southwest. PNAS 106:2110-2113.

Crown, Patricia L., and Wirt H. Wills

2003 Modifying Pottery and Kivas at Chaco: Pentimento, Restoration, or Renewal? American Antiquity 68:511532.

Day, Peter, and David Wilson

2004 Ceramic Change and the Practice of Eating and Drinking in Early Bronze Age Crete. In Food, Cuisine and Society in Prehistoric Greece, edited by Paul Halstead and John C. Barrett, pp. 45-62. Oxbow Books, Oxford.

Dietler, Michael

1990 Driven by Drink: The Role of Drinking in the Political Economy and the Case of Early Iron Age France. Journal of Anthropological Archaeology 9:352406.

2001 Theorizing the Feast: Rituals of Consumption, Commensal Politics, and Power in African Contexts. In Feasts: Archaeological and Ethnographic Perspectives on Food, Politics and Power, edited by Michael Dietler and Brian Hayden, pp. 65-114. Smithsonian Press, Washington, DC.

2006 Alcohol: Anthropological/Archaeological Perspectives. Annual Review of Anthropology 35:229-249.

Dietler, Michael, and Ingrid Herbich

1989 Tich Matek: The Technology of Luo Pottery Production and the Definition of Ceramic Style. World Archaeology 21:148-164.

Douglas, Mary

1987 A Distinctive Anthropological Perspective. In Constructive Drinking: Perspectives on Drink from Anthropology, edited by Mary Douglas, pp. 3-15. Cambridge University Press, Cambridge.

Driver, Harold

1969 Indians of North America. University of Chicago, Chicago.

Elias, Norbert

1994 The Civilizing Process. Translated by Edmund Jephcott. Blackwell Publishers, Oxford.

Hamilakis, Yannis

1999 Food Technologies/Technologies of the Body: The Social Context of Wine and Oil Production and Consumption in Bronze Age Crete. World Archaeology 31:38-54.

2008 Time, Performance, and the Production of a Mnemonic Record: From Feasting to an Archaeology of Eating and Drinking. In DAIS: The Aegean Feast, edited by Louise Hitchcock, Robert Laffineur, and Janice Crowley, pp. 3-20. Aegaeum, Vol. 29. Peeters Publishers, Leuven, Belgium.

Havard, Valery

1896 Drink Plants of the North American Indians. Bulletin of the Torrey Botanical Club 23(2):33-46.

Hayden, Brian

1995 The Emergence of Prestige Technologies and Pottery. In The Emergence of Pottery, edited by William K.
Barnett and John W. Hoopes, pp. 257-266. Smithsonian Institution Press, Washington, DC.

2001 Fabulous Feasts: A Prolegomenon to the Importance of Feasting. In Feasts: Archaeological and Ethnographic Perspectives on Food, Politics, and Power, edited by Michael Dietler and Brian Hayden, pp. 23-64. Smithsonian Institution Press, Washington, DC.

Heath, Dwight B.

2000 Drinking Occasions: Comparative Perspectives on Alcohol and Culture. Brunner/Mazel, Philadelphia.

Henderson, John S., and Rosemary A. Joyce

2006 Brewing Distinction: The Development of Cacao Beverages in Formative Mesoamerica. In Chocolate in Mesoamerica: A Cultural History of Cacao, edited by Cameron L. McNeil, pp. 140-153. University of Florida Press, Gainesville.

Henrich, Joseph

2010 The Evolution of Innovation-Enhancing Institutions. In Innovation in Cultural Systems: Contributions from Evolutionary Anthropology, edited by Michael J. O'Brien and Stephen J. Shennan, pp. 99-120. MIT Press, Cambridge, Massachusetts.

Holmes, William H.

1886 Origin and Development of Form and Ornament in Ceramic Art. In Fourth Annual Report of the Bureau of Ethnology, pp. 443-465. US Government Printing Office, Washington, DC.

Houston, Stephen

2014 The Life Within: Classic Maya and the Matter of Permanence. Yale University Press, New Haven, Connecticut.

Jennings, Justin, Kathleen L. Antrobus, Sam J. Atencio, Erin Glavich, Rebecca Johnson, German Loffler, and Christine Luu

2005 "Drinking Beer in a Blissful Mood": Alcohol Production, Operational Chains, and Feasting in the Ancient World. Current Anthropology 46:275-303.

Joffe, Alexander $\mathrm{H}$.

1998 Alcohol and Social Complexity in Ancient Western Asia. Current Anthropology 39:297-322.

Joyce, Rosemary, and John S. Henderson

2010 Forming Mesoamerican Taste: Cacao Consumption in Formative Period Contexts. In Pre-Columbian Foodways: Interdisciplinary Approaches to Food, Culture and Markets in Ancient Mesoamerica, edited by John E. Staller and Michael D. Carrasco, pp. 157-173. Springer, New York.

Judd, Neil M.

1954 The Material Culture of Pueblo Bonito. Smithsonian Miscellaneous Collections, Vol. 124. Smithsonian Institution, Washington, DC.

Kessell, John, and Richard Hendricks

1992 By Force of Arms: The Journals of Don Diego De Vargas, New Mexico 1691-1693. University of New Mexico Press, Albuquerque.

Knappett, Carl

2011 An Archaeology of Interaction: Network Perspectives on Material Culture and Society. Oxford University Press, Oxford.

La Barre, Weston

1938 Native American Beers. American Anthropologist 40:224-234.

LeCount, Lisa

1999 Polychrome Pottery and Political Strategies in Late and Terminal Classic Lowland Maya Society. Latin American Antiquity 10:239-258. 
Lekson, Stephen

1984 Great Pueblo Architecture of Chaco Canyon. Chaco Canyon Studies, Publications in Archaeology 18B. National Park Service, Albuquerque, New Mexico.

Liebmann, Matthew

2015 The Mickey Mouse Kachina and Other "Double Objects": Hybridity in the Material Culture of Colonial Encounters. Journal of Social Archaeology 15:319-341.

Lister, Robert H., and Florence C. Lister

1978 Anasazi Pottery. University of New Mexico Press, Albuquerque.

Lucero, Lisa J.

2008 Memorializing Place among Classic Maya Commoners. In Memory Work: Archaeologies of Material Practices, edited by Barbara J. Mills and William H. Walker, pp. 187-205. School for Advanced Research, Santa Fe, New Mexico.

McNeil, Cameron L. (editor)

2006 Chocolate in Mesoamerica: A Cultural History of Cacao. University of Florida Press, Gainesville.

Marden, Kerriann

2011 Taphonomy, Paleopathology and Mortuary Variability in Chaco Canyon: Using Bioarchaeological and Forensic Methods to Understand Ancient Cultural Practices. PhD dissertation, Department of Anthropology, Tulane University, New Orleans, Louisiana.

Mathiowetz, Michael Dean

2011 The Diurnal Path of the Sun: Ideology and Interregional Interaction in Ancient Northwest Mesoamerica and the American Southwest. PhD dissertation, Department of Anthropology, University of California, Riverside.

Merrill, William L.

1979 The Beloved Tree-Ilex vomitoria among the Indians of the Southeast and Adjacent Regions. In Black Drink: A Native American Tea, edited by Charles M. Hudson, pp. 40-82. University of Georgia Press, Athens.

Merrill, William L., and Maria Sprehn

2002 Feasting and Alcohol in the North American Southwest. Paper presented at the 8th Biennial Meeting of the Southwest Symposium, University of Arizona, Tucson. Mills, Barbara

1993 Functional Variation in the Ceramic Assemblages. In Across the Colorado Plateau: Anthropological Studies for the Transwestern Pipeline Expansion Project, Vol. XVI, by Barbara Mills, Christine Goestze, and María Nieves Zedeño, pp. 301-346. Office of Contract Archaeology and Maxwell Museum of Anthropology, University of New Mexico, Albuquerque.

2004 The Establishment and Defeat of Hierarchy: Inalienable Possessions and the History of Collective Prestige Structure in the Pueblo Southwest. American Anthropologist 106:238-251.

2008 Remembering while Forgetting: Depositional Practices and Social Memory at Chaco. In Memory Work: Archaeologies of Material Practices, edited by Barbara J. Mills and William H. Walker, pp. 81-108. School for Advanced Research, Santa Fe, New Mexico.

Mills, Barbara J., and T. J. Ferguson

2008 Animate Objects: Shell Trumpets and Ritual Networks in the Greater Southwest. Journal of Archaeological Method and Theory 15:338-361.

Mullins, Paul R.

2011 The Archaeology of Consumption. Annual Review of Anthropology 40:133-144.

Neitzel, Jill E., and Ronald L. Bishop

1990 Neutron Activation of Dogoszhi Style Ceramics: Production and Exchange in the Chacoan Regional System. Kiva 50:67-86.

Ortiz, Alphonso

1969 The Tewa World. University of Chicago Press, Chicago.

Parsons, Elsie Clews

1939 Pueblo Indian Religion. University of Chicago Press, Chicago.

Pepper, George $\mathrm{H}$.

1920 Pueblo Bonito. Anthropological Papers of the American Museum of Natural History Vol. 27. American Museum of Natural History, New York.

Plog, Stephen, and Adam S. Watson

2012 The Chaco Pilgrimage Model: Evaluating the Evidence from Pueblo Alto. American Antiquity 77:449 477.

Post, Stephen S.

1989 A Dual Cylinder Vessel from a Pueblo II-III Site near Black Hat, McKinley County, New Mexico. Pottery Southwest 16(2):1-3.

Potter, James

2000 Pots, Parties, and Politics: Communal Feasting in the American Southwest. American Antiquity 65:471492.

Powis, Terry, Fred Valdez Jr., Thomas R. Hester, W. Jeffrey Hurst, and Stanley M. Tarka

2002 Spouted Vessels and Cacao Use among the Preclassic Maya. Latin American Antiquity 13:85-106.

Pugh, Timothy W.

2009 Contagion and Alterity: Kowoj Maya Appropriations of European Objects. American Anthropologist 111:373-386.

Putsavage, Katy J.

2008 Mesa Verde Style Mugs: An Analysis of Domestic and Ritual Functions. Master's thesis, Department of Anthropology, University of Colorado, Boulder.

Rabinowitz, Adam

2009 Drinking from the Same Cup: Sparta and Late Archaic Commensality. In Sparta: Comparative Approaches, edited by Stephen Hodkinson, pp. 113192. Classical Press of Wales, Swansea.

Reents-Budet, Dorie

2006 The Social Context of Kakaw Drinking among the Ancient Maya. In Chocolate in Mesoamerica: A Cultural History of Cacao, edited by Cameron McNeil, pp. 202-223. University Press of Florida, Gainesville.

Roberts, Frank H. H.

1930 Early Pueblo Ruins in the Piedra District, Southwestern Colorado. Bureau of American Ethnology Bulletin No. 96. US Government Printing Office, Washington, DC.

Sherratt, Andrew

1995 Alcohol and Its Alternatives: Symbol and Substance in Pre-industrial Societies. In Consuming Habits: Drugs in History and Anthropology, edited by Jordan Goodman, Paul E. Lovejoy, and Andrew Sherratt, pp. 11-46. Routledge, London.

Smith, Frederick H.

2008 The Archaeology of Alcohol and Drinking. University Press of Florida, Gainesville.

Smith, Michael, Jennifer Wharton, and Ian Marie Olson

2003 Aztec Feasts, Rituals and Markets: Political Uses of Ceramic Vessels in a Commercial Economy. In 
The Archaeology and Politics of Food and Feasting in Early States and Empires, edited by Tamara Bray, pp. 235-268. Kluwer Academic Publishing, Hingham, Massachusetts.

Snow, Cordelia

2005 Objects Supporting Ideas: A Study of Archaeological Majolica and Polite Behavior in New Mexico, 1598-1846. In Inscriptions: Papers in Honor of Richard and Nathalie Woodbury, edited by Regge N. Wiseman, Thomas C. O'Laughlin, and Cordelia T. Snow, pp. 187 198. Annual Vol. 31. Archaeological Society of New Mexico, Albuquerque.

Spielmann, Kate

2002 Feasting, Craft Specialization, and the Ritual Mode of Production in Small-Scale Societies. American Anthropologist 104:195-207.

2004 Communal Feasting, Ceramics, and Exchange. In Identity, Feasting, and the Archaeology of the Greater Southwest, edited by Barbara J. Mills, pp. 210-232. University Press of Colorado, Boulder.

Stevenson, Mathilda Coxe

1915 Ethnobotany of the Zuni Indians. Annual Report of the Bureau of American Ethnology, Vol. 30. US Government Printing Office, Washington, DC.

Stockhammer, Philipp W.

2012 Performing the Practice Turn in Archaeology. Transcultural Studies 1:7-42.

Taussig, Michael

1993 Mimesis and Alterity: A Particular History of the Senses. Routledge, New York.

Tedlock, Dennis

2002 How to Drink Chocolate from a Skull at a Wedding Banquet. RES: Anthropology and Aesthetics 42:166179.

Toll, H. Wolcott

1990 A Reassessment of Chaco Cylinder Jars. In Clues to the Past: Papers in Honor of William Sundt, edited by Meliha S. Duran and David T. Kirkpatrick, pp. 273-305. Archaeological Society of New Mexico Papers No. 16. Archaeological Society of New Mexico, Albuquerque.

Toll, H. Wolcott, and Peter McKenna

1997 Chaco Ceramics. In Ceramics, Lithics and Ornaments of Chaco Canyon: Analyses of Artifacts from the Chaco Project 1971-1978, edited by Joan Mathien, pp. 17-530. Chaco Canyon Studies, Publications in Archaeology 18G. National Park Service, Santa Fe, New Mexico.

van der Veen, Marijke

2003 When Is Food a Luxury? World Archaeology 34:405-427.

Van Keuren, Scott

2004 Crafting Feasts in the Prehispanic Southwest. In Identity, Feasting, and the Archaeology of the Greater Southwest, edited by Barbara Mills, pp. 192-209. University of Colorado Press, Boulder.

Vencl, Slavomil

1994 The Archaeology of Thirst. Journal of European Archaeology 2:299-326.

Waddell, Jack O.

1980 The Use of Intoxicating Beverages among Native Peoples of the Aboriginal Greater Southwest. In Drinking Behavior among the Southwestern Indians, edited by Jack O. Waddell and Michael W. Everett, pp. 1-34. University of Arizona Press, Tucson.
Washburn, Dorothy K.

1980 The Mexican Connection: Cylinder Jars from the Valley of Oaxaca. In New Frontiers in the Archaeology and Ethnohistory of the Southwest, edited by Carroll L. Riley and Basil C. Hedrick, pp. 70-85. Transactions of the Illinois State Academy of Science, Vol. 72, No. 4. Illinois State Academy of Science, Springfield.

2008 The Position of Salmon Ruins in the Middle San Juan, AD 1000-1300: A Perspective from Ceramic Design Structure. In Chaco's Northern Prodigies, edited by Paul F. Reed, pp. 284-308. University of Utah Press, Salt Lake City.

Washburn, Dorothy K., William Washburn, and Paulina Shipkova

2011 The Prehistoric Drug Trade: Widespread Consumption of Cacao in Ancestral Pueblo and Hohokam Communities in the American Southwest. Journal of Archaeological Science 38:1634-1640.

2013 Cacao Consumption during the 8th Century at Alkali Ridge, Southeastern Utah. Journal of Archaeological Science 40:2007-2013.

Webb, Jennifer M., and David Frankel

2008 Fine Ware Ceramics, Consumption and Commensality: Mechanisms of Horizontal and Vertical Integration in Early Bronze Age Cyprus. In DAIS: The Aegean Feast, edited by Louise Hitchcock, Robert Laffineur, and Janice Crowley, pp. 287-295. Aegaeum, Vol. 29. Peeters Publishers, Leuven, Belgium.

Wills, Wirt H., and Patricia L. Crown

2004 Community and Cuisine in the Prehispanic American Southwest. In Identity, Feasting, and the Archaeology of the Greater Southwest, edited by Barbara J. Mills, pp. 153-172. University Press of Colorado, Boulder.

Wright, James C.

2004 Mycenaean Drinking Services and Standards of Etiquette. In Food, Cuisine and Society in Prehistoric Greece, edited by Paul Halstead and John C. Barrett, pp. 90-104. Oxbow Books, Oxford.

\section{Notes}

1. Cylinder vases occur in the Maya region during the Late Classic period (AD 550-950) from Chiapas to northern Honduras and El Salvador (Dorie Reents-Budet, personal communication 2017). Cylinder jars were also made in Sinaloa and Nayarit in western Mexico between AD 900 and 1350 (Mathiowetz 2011:554), so Chaco potters may have emulated the shape from a number of sources in Mesoamerica or independently invented it.

2. There is a vessel described as a cylinder jar from southern Colorado (Piedra District) in a Pueblo I context dating sometime between AD 700 and 900 (Roberts 1930:107); the vessel is shorter $(13.1 \mathrm{~cm})$ than most Chacoan cylinder jars.

3. Mathiowetz has recently argued that cacao-drinking in Chaco Canyon was part of "a newly burgeoning but incomplete form of the Flower World Complex" (2011:702).

Submitted June 28, 2017; Revised January 5, 2018; Accepted February 2, 2018 